\title{
Leaf Functional Traits Study of Native Trees in Different City
}

\section{Environment}

\author{
Yu-Dan Sun ${ }^{+*}$, Jin-Xiang Liu ${ }^{+}$and Ping-Hui Huo \\ Life Science and Technology School, Lingnan Normal University, Zhanjiang, 524048, China \\ Burningice80@163.com, lightlong@163.com, lovelymabelhuo@126.com \\ +The author contributed equally to this work \\ *For correspondence: Burningice80@163.com
}

Keywords: native trees; leaf functional traits; different environment; response

Abstract: To reveal the effects of the different city environment (clean area and polluted area) on native trees, leaf functional traits of six native trees in Zhanjiang were studied. The relationship between leaf mass per area (LMA) and leaf functional traits were analyzed. The results showed that different leaf functional traits of the six native trees show difference in different environment. The fresh weight (FW) of Ficus microcarpa L.f., Hibiscus rosa-sinensis Linn, Ixora chinensis Lam.and Lagerstroemia speciosa (L.) Pers. in the two environments is different among each other significantly $(\mathrm{p}<0.05)$.The specific leaf area (SLA) of Ficus virens Aiton, Hibiscus rosa-sinensis Linn., Ixora chinensis Lam., Dracontomelon duperreanum Pierre and Lagerstroemia speciosa (L.) Pers. which growing in clean area was significantly higher than in polluted area $(\mathrm{P}<0.01)$, no significant SLA difference was found on Ficus microcarpa L.f. in the two environments $(\mathrm{P}>0.05)$. LMA shows extremely significantly positive correlation with fresh weight and dry weight $(\mathrm{p}<0.01$, $\left.\mathrm{r}^{2}=0.186 ; \mathrm{p}<0.01, \mathrm{r}^{2}=0.0806\right)$, and shows a weak significantly positive correlation to leaf area $(\mathrm{p}$ $<0.05, \mathrm{r}^{2}=0.0048$ ), and it also shows a weak significantly negative correlation with width -length ratio ( $\mathrm{p}<0.01, \mathrm{r}^{2}=0.0173$ ), and a significant moderate-intensity negative correlation with water content $\left(\mathrm{p}<0.01, \mathrm{r}^{2}=0.4604\right)$, but no difference is found with average width.

\section{Introduction}

Plant functional traits (PFT) is an important property influencing the colonization, subsistence and adaptation and that is involved with the capability of obtaining, utilizing and preserving resources[1,2]. In recent years, the relationship between PFT and environmental factors has been attracting more and more attention[3,4,5]. The relationship between PFT and environmental factors is the screening result of climate, interference and biological conditions[6]. PFT have been used to describe the response of native vegetation to environmental factors[7]. As an important plant organ, the functional traits of leaf can effectively reflect the habitat conditions, incarnating plant survival strategy under specific environment and the response to environmental changes[8,9]. The functional traits of leaf include specific leaf area(SLA), thickness(TH), fresh weight(FW), dry weight(DW) and dry matter content(DMC), etc[10,11], which were formed gradually by means of heritable variation and natural selection in the long-term effects of the external environment condition (especially the climate conditions) on plant, and can reflect a series of survival strategies including gas exchange, energy absorption, carbon fixation etc on plants better in different environmental conditions, such as environment with sufficient or insufficient factors. The text studied on leaf functional traits of six native trees in Zhanjiang, analyzed the traits of the differences between 
different environment, and discussed the response of native plant to environmental characteristics.

\section{Sampling}

We selected six native greening trees which were widely applied in landscape architecture (Table 1) in different environment (polluted area and clean area). The study in polluted area was conduct along the main road in Zhanjiang, and clean area including Cunjinqiao Park and Forest park. For every tree, we chose ten growing well individuals for repeated sampling in July 2015; all individuals kept a consistent diameter at breast height to avoid the influence of tree age. Then selected four current-growth branches with consistent light environment in different direction in the central canopy for every individual, and then chose a slice of mature, complete and healthy typical leaf between $5^{\text {th }}$ leaf from the top and $5^{\text {th }}$ leaf from the bottom. Wipe clean the leaf with filter paper, and kept it in a sealed bag for laboratory determination.

$\begin{array}{cccc} & \text { Table } 1 \text { General characteristics of native trees } & & \\ \text { Species } & \text { Family } & \text { Genus } & \text { Growth form } \\ \text { Ficus virens Aiton. } & \text { Moraceae } & \text { Ficus } & \text { Deciduous or semi-deciduous trees } \\ \text { Dracontomelon duperreanum Pierre. } & \text { Anacardiaceae } & \text { Dracontomelon } & \text { Ficus } \\ \text { Ficus microcarpa L.f. } & \text { Moraceae } & \text { Lagerstroemia } & \text { Deciduous or semi-deciduous trees } \\ \text { Lagerstroemia speciosa }(\text { L. }) \text { Pers. } & \text { Lythraceae } & \text { Hibiscus } & \text { Evergreen shrubs } \\ \text { Hibiscus rosa-sinensis Linn. } & \text { Malvaceae } & \text { Ixora } & \text { Evergreen shrubs }\end{array}$

\section{Determination of leaf functional traits}

Numbered all the leaves sequentially, weighed fresh weight (FW) of each leaf with a 1/100 balance, and scanned leaf by Epson Perfection V700 Photo scanner, then calculate indexes including leaf area, leaf length, leaf width and length-width ratio using WinFolia 7.0. Leaf width is the width at the widest point, and average width refers to the width of average from the blade tip to petiole. Put the leaf into the oven at $105^{\circ} \mathrm{C}$ for 15 minutes after scanning, dried to a constant weight at $80{ }^{\circ} \mathrm{C}$, and weighed leaf dry weight (DW).Leaf thickness (TH) were measured by vernier calipers (precision $0.02 \mathrm{~mm}$ ) at the top, middle and bottom of each leaf, measuring position were about 0.25 $\mathrm{cm}$ on both sides of the main vein of leaves. Specific leaf area (SLA), leaf mass per area (LMA) and moisture content are calculated by the following formula:

$$
\begin{aligned}
& \mathrm{SLA}\left(\mathrm{cm}^{2} \mathrm{~g}^{-1}\right)=\text { leaf area }\left(\mathrm{cm}^{2}\right) / \mathrm{DW}(\mathrm{g}) \\
& \text { Moisture content }(\%)=\mathrm{FW}(\mathrm{g})-\mathrm{DW}(\mathrm{g}) / \mathrm{FW}(\mathrm{g})
\end{aligned}
$$

$\operatorname{LMA}\left(\mathrm{mg} \mathrm{cm}^{-2}\right)=\mathrm{DW}(\mathrm{g}) /$ leaf area $\left(\mathrm{cm}^{2}\right)$

\section{Data analysis}

The structural traits data were used for statistical analysis, difference of the characters between different environments was analyzed by independent samples $\mathrm{T}$ test using SPSS17.0. Correlation analysis between leaf mass per area and structural characters Kruskal-Wallis test used SASTISTICA 8.0. Significance level $\mathrm{P}$ is 0.05 ; data keep two decimal fractions; standard errors are rounding errors.

\section{Result and Analysis}

\section{Comparison of fresh weight and leaf morphology}

The different leaf structural indexes of six native trees show difference in clean area and polluted area (Table 2). The fresh weight of Ficus virens Aiton. and Dracontomelon duperreanum 
Pierre. in the two different habitats is non-significant difference ( $\mathrm{p}>0.05)$, while Ficus microcarpa L.f., Hibiscus rosa-sinensis Linn., Ixora chinensis Lam. and Lagerstroemia speciosa (L.) Pers. showed significant differences $(\mathrm{p}<0.05)$. The length and the width of leaf, the average width of leaf of Ficus virens Aiton. in clean area were significantly greater than in polluted area. But the non-significant difference is found in the Width to length ratio the length of leaf, the width to length ratio of Ficus concinna all shows important difference in different habitats, while the width of leaf and the average width of leaf is non-significant difference; and the width of leaf, the average width of leaf and the width to length ratio of Hibiscus rosa-sinensis Linn. In polluted area were significantly greater than in clean area, but the length of leaf in clean area is greater than polluted area; all indicators of Ixora chinensis Lam. Show significant difference in two different environment and the leaf length, the leaf width, and the average width of leaf in polluted area were greater than in clean area, but the width to length ratio in clean area is greater than in polluted area; the leaf length, the leaf width and the average width of leaf of Dracontomelon duperreanum Pierre. in clean area were significantly greater than in polluted area, but their width to length ratio shows non-significant difference; the leaf length of Lagerstroemia speciosa (L.) Pers. in clean area is greater than in polluted area, while its width of leaf in polluted area is greater than in clean area, while its other indicators were non-significant difference in different environment. Results show that the fresh weight and structural indexes of leaf of six native trees had no significant regularity from clean area and polluted area, what may be due to the change created by the difference of tree species.

Table 2 Leaf functional traits of 6 native trees in different environment

\begin{tabular}{|c|c|c|c|c|c|c|}
\hline Specie & Site & Fresh weigh ( g ) & Length $(\mathrm{cm})$ & $\begin{array}{l}\text { Width } \\
(\mathrm{cm})\end{array}$ & $\begin{array}{l}\text { Avewidth } \\
(\mathrm{cm})\end{array}$ & $\begin{array}{l}\text { Width / } \\
\text { Length }\end{array}$ \\
\hline Ficus virens Aiton & clean area & $1.34 \pm 0.06 \mathrm{a}$ & $14.63 \pm 0.23 \mathrm{a}$ & $6.67 \pm 0.16 \mathrm{a}$ & $4.87 \pm 0.13 \mathrm{a}$ & $0.46 \pm 0.01 \mathrm{a}$ \\
\hline Ficus virens Aiton & polluted area & $1.29 \pm 0.05 \mathrm{a}$ & $13.53 \pm 0.24 b$ & $6.12 \pm 0.1 \mathrm{~b}$ & $4.46 \pm 0.08 \mathrm{~b}$ & $0.46 \pm 0.01 \mathrm{a}$ \\
\hline Ficus microcarpa L.f. & clean area & $0.41 \pm 0.01 \mathrm{a}$ & $7.27 \pm 0.12 \mathrm{a}$ & $3.7 \pm 0.06 \mathrm{a}$ & $2.49 \pm 0.04 \mathrm{a}$ & $0.51 \pm 0.01 \mathrm{a}$ \\
\hline Ficus microcarpa L.f. & polluted area & $0.49 \pm 0.01 \mathrm{~b}$ & $7.84 \pm 0.11 b$ & $3.62 \pm 0.05 \mathrm{a}$ & $2.4 \pm 0.03 \mathrm{a}$ & $0.46 \pm 0.01 \mathrm{~b}$ \\
\hline Hibiscus rosa-sinensis Linn. & clean area & $0.4 \pm 0.01 \mathrm{a}$ & $7.52 \pm 0.09 \mathrm{a}$ & $4.29 \pm 0.07 \mathrm{a}$ & $2.85 \pm 0.05 \mathrm{a}$ & $0.57 \pm 0.01 \mathrm{a}$ \\
\hline Hibiscus rosa-sinensis Linn. & polluted area & $0.85 \pm 0.03 \mathrm{~b}$ & $7.11 \pm 0.11 \mathrm{~b}$ & $5.55 \pm 0.09 \mathrm{~b}$ & $3.87 \pm 0.07 \mathrm{~b}$ & $0.78 \pm 0.01 \mathrm{~b}$ \\
\hline Ixora chinensis Lam. & clean area & $0.3 \pm 0.01 \mathrm{a}$ & $5.74 \pm 0.1 \mathrm{a}$ & $2.69 \pm 0.04 \mathrm{a}$ & $1.88 \pm 0.03 \mathrm{a}$ & $0.47 \pm 0.01 \mathrm{a}$ \\
\hline Ixora chinensis Lam. & polluted area & $0.49 \pm 0.01 \mathrm{~b}$ & $8.34 \pm 0.12 b$ & $2.95 \pm 0.04 \mathrm{~b}$ & $2.1 \pm 0.03 \mathrm{~b}$ & $0.36 \pm 0 \mathrm{~b}$ \\
\hline Dracontomelon duperreanum Pierre & clean area & $0.76 \pm 0.03 \mathrm{a}$ & $14.74 \pm 0.21 \mathrm{a}$ & $4.2 \pm 0.08 \mathrm{a}$ & $2.85 \pm 0.06 \mathrm{a}$ & $0.29 \pm 0.01 \mathrm{a}$ \\
\hline Dracontomelon duperreanum Pierre & polluted area & $0.72 \pm 0.02 \mathrm{a}$ & $13.8 \pm 0.21 \mathrm{~b}$ & $3.97 \pm 0.06 \mathrm{~b}$ & $2.66 \pm 0.04 \mathrm{~b}$ & $0.29 \pm 0 \mathrm{a}$ \\
\hline Lagerstroemia speciosa (L.) Pers. & clean area & $3.05 \pm 0.12 \mathrm{a}$ & $22.49 \pm 0.31 \mathrm{a}$ & $8.89 \pm 0.14 \mathrm{a}$ & $6.12 \pm 0.11 \mathrm{a}$ & $0.4 \pm 0.01 \mathrm{a}$ \\
\hline Lagerstroemia speciosa (L.) Pers. & polluted area & $3.86 \pm 0.12 \mathrm{~b}$ & $20.77 \pm 0.27 \mathrm{~b}$ & $8.75 \pm 0.11 \mathrm{a}$ & $5.99 \pm 0.08 \mathrm{a}$ & $0.42 \pm 0.01 \mathrm{~b}$ \\
\hline
\end{tabular}

Data followed different letters within column of the same tree indicate significant differences at 0.05 level.

\section{The difference of leaf area, dry weight and leaf water content}

There was different performance in leaf area, dry weight and leaf water content of six different species in different environment (Figure 1). We found that the leaf area of Ficus virens Aiton., Dracontomelon duperreanum Pierre. and Lagerstroemia speciosa (L.) Pers. in clean area was significantly higher than in polluted area, while Hibiscus rosa-sinensis Linn. and Ixora chinensis Lam. in clean area was significantly less than that in polluted areas. No significant difference was found about the leaf area of Ficus microcarpa L.f. in two environments. Dry weight of Hibiscus rosa-sinensis Linn., Ixora chinensis Lam. and Lagerstroemia speciosa (L.) Pers. in polluted areas was significantly higher than that in clean area, but there was no significant difference among Ficus virens Aiton., Ficus microcarpa L.f. and Dracontomelon duperreanum Pierre. The leaf water 
content of Ficus microcarpa L.f. and Hibiscus rosa-sinensis Linn. in polluted area showed significantly larger than that in clean area, while the leaf water content of Ixora chinensis Lam., Dracontomelon duperreanum Pierre. and Lagerstroemia speciosa (L.) Pers. in clean area was significantly greater than that in polluted area, and Ficus virens Aiton. was no significant difference in different environment.

\section{Performance of specific leaf area of habitat heterogeneity}

Specific leaf area (SLA) is the light capture area of per unit dry mass, related to plant assimilation rate, reflects the ability of plants to acquire resources, is closely related to the survival and growth of plants. We can conclude from that the SLA of Ficus virens Aiton., Hibiscus rosa-sinensis Linn., Ixora chinensis Lam., Dracontomelon duperreanum Pierre., Lagerstroemia speciosa (L.) Pers. which growing in clean area was significantly higher than in polluted areas $(\mathrm{P}<$ 0.01), Ficus microcarpa L.f. in two environments without significant difference $(\mathrm{P}>0.05)$ (Figure 2 ). The results show that the responses of five native trees in different environment are consistency, showed the SLA of plants in clean area is greater than in polluted area .

\section{Correlativity between leaf mass per area and different leaf structure factors}

Leaf mass per area(LMA) is dry mass per unit leaf area, representing carbon sequestration capacity and assimilation efficiency of leaf more intuitively. As seen in the Figure 3, LMA shows positive correlation and extremely significant difference to fresh weight and dry weight of leaf

$\left(\mathrm{p}<0.01, \mathrm{r}^{2}=0.186 ; \mathrm{p}<0.01, \mathrm{r}^{2}=0.0806\right)$, meanwhile a weak positive correlation to leaf area $(\mathrm{p}<0.05$, $r^{2}=0.0048$ ), and it also shows a weak negative correlation and extremely significant difference to width to length ratio $\left(\mathrm{p}<0.01, \mathrm{r}^{2}=0.0173\right)$, a moderate-intensity negative correlation and extremely significant difference to water content $\left(\mathrm{p}<0.01, \mathrm{r}^{2}=0.4604\right)$, but it shows non-significant difference to average width.
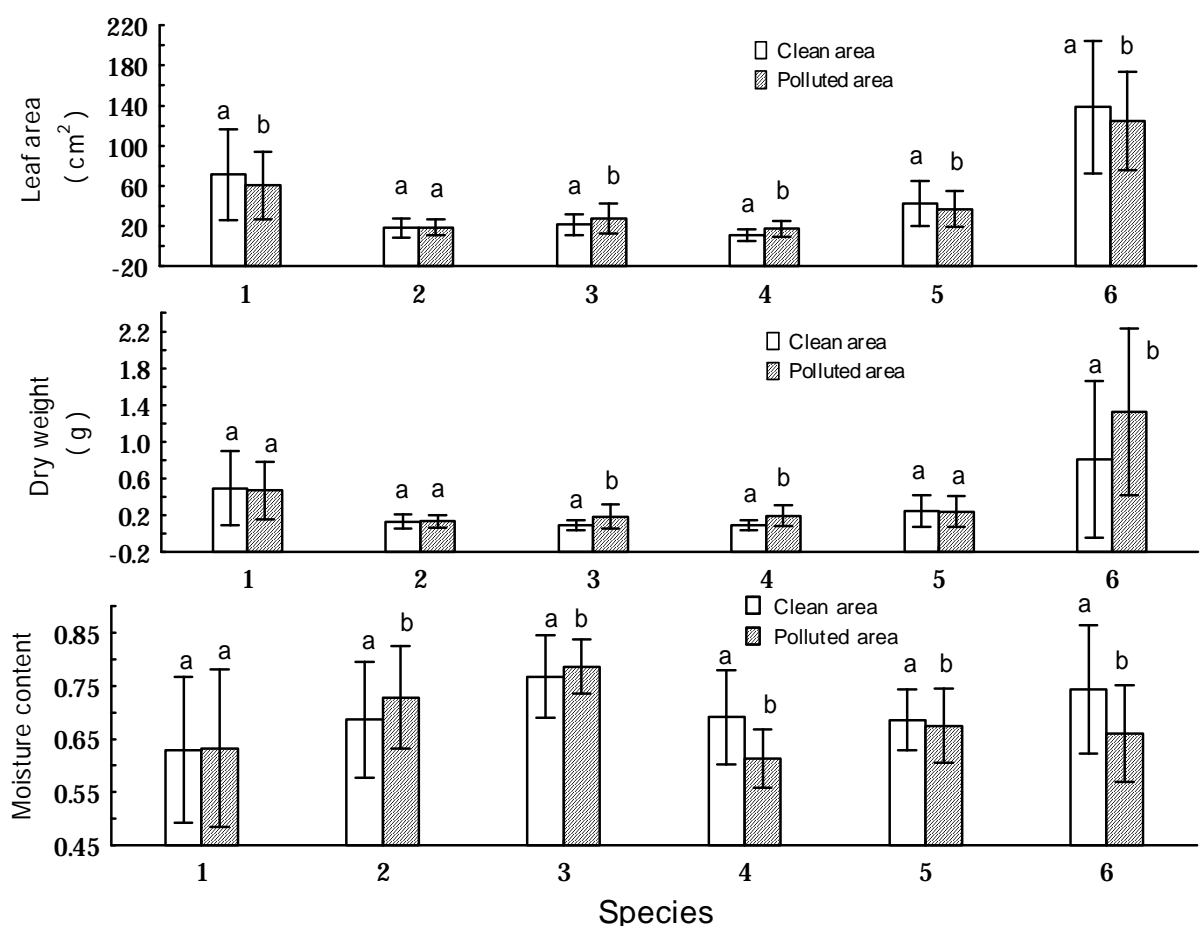

Fig. 1 Differences in dry weight, leaf area and moisture content of leaves of 6 native trees between different environment.

( Different letters above column of the same species indicate significant difference at 0.05 level).

1. Ficus virens Aiton. 2. Ficus microcarpa L.f. 3. Hibiscus rosa-sinensis Linn.;

4.Ixora chinensis Lam. 5.Dracontomelon duperreanum Pierre 6.Lagerstroemia speciosa (L.) Pers. 


\section{Conclusion and discussion}

Leaf functional traits reflecting plant adaptation to environment and resource utilization rate, are sensitive to environmental changes and vary with habitat changes[12]. During the adaptation to habitat, leaf functional traits will show functional correlation with habitat and trade-off[13]. We tested difference in leaf functional traits of six native trees under various environment and detected differences in fresh weight, leaf length, leaf width, mean width, leaf area, dry weight and leaf water content among six trees. However, no consistent trend was observed. Ficus microcarpa L.f. did not change with habitat, which indicated that leaf functional traits changed with habitat and responses to environment were uncertain.
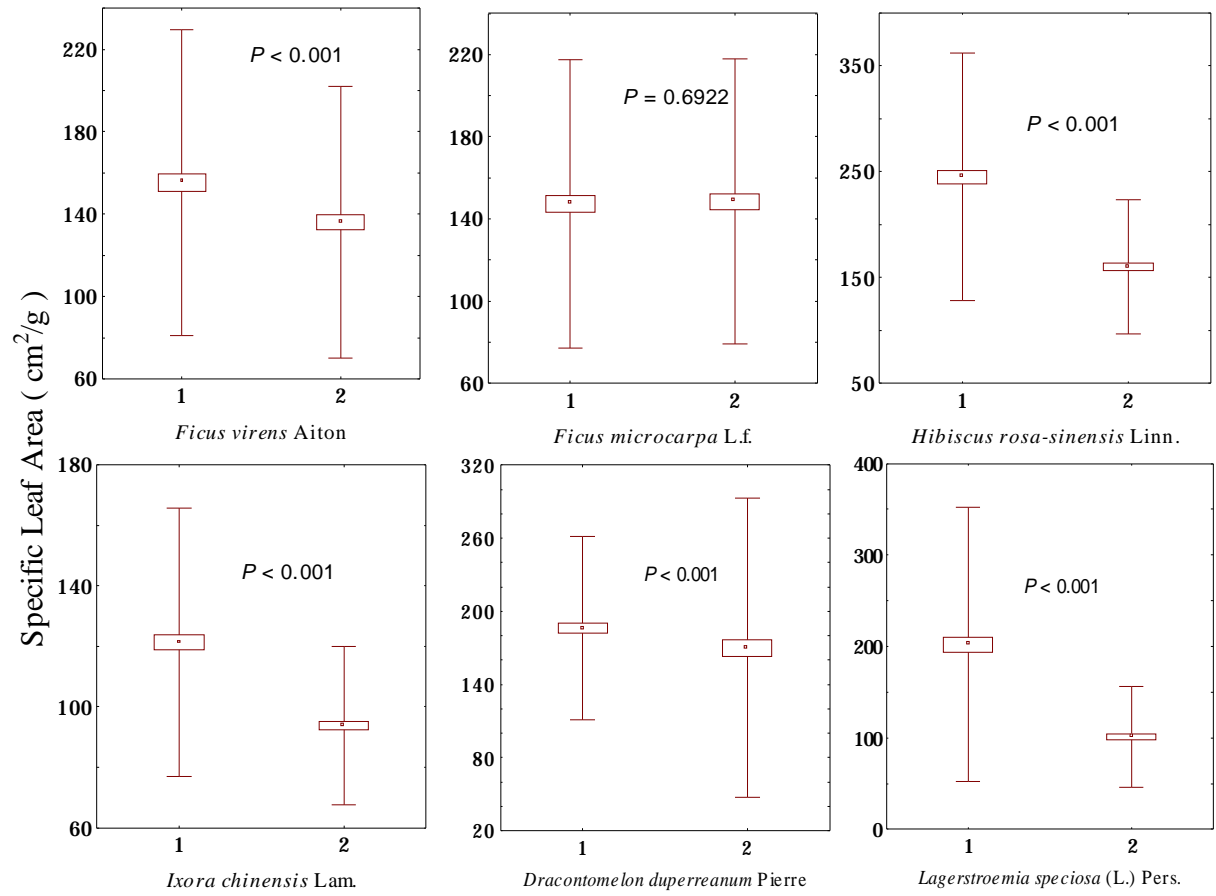

Site

Fig. 2 Differences in SLA ( Specific Leaf Area ) of 6 native trees between different environment ( $\square: \quad 25 \%-75 \%$; I: Non-outlier range).1. Clean area 2. Polluted area
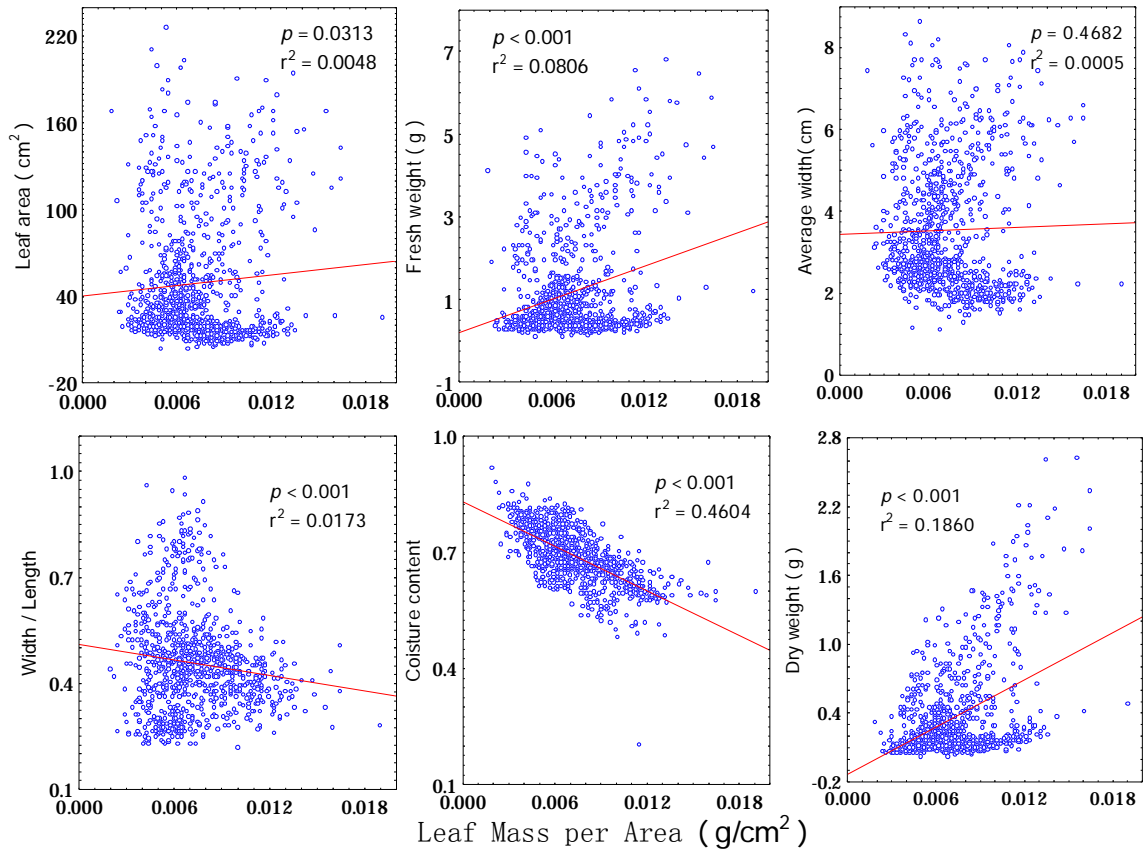

Fig. 3 Correlation between LMA and other leaf functional traits 
Special leaf area (SLA) indicative of resource acquisition and water utilization capacity of plant is correlated with adaptability of plant to environment[14]. For example, plants with small SLA are more resistant against drought, while those with large SLA are better to conserve nutrition[15]. SLA of Ficus virens Aiton, Dracontomelon duperreanum Pierre., Lagerstroemia speciosa (L.) Pers., Hibiscus rosa-sinensis Linn. and Ixora chinensis Lam. in clean area were larger than in polluted area, which indicated that polluted area were more suitable for plant to survive and grow than clean area. Leaf shape of five species in streets varied with environmental stress due to pollution, which led to larger SLA.

Leaf mass per area (LMA), characterizing carbon sequestration capacity of plants, reflects correlations of per unit leaf area with resource utilization. LMA of plants is large under drought and barrenness [16]. Wright et al[17]found negative correlations of LMA with water and precipitation after investigating 75 species of plant in the eastern Australia, which was consistent with our findings. We also found that LMA was correlated most significantly with water content among all tested factors, which suggested water was the requisite for resource utilization in plants.

This paper tested the adaptability of native trees under different environment. Results suggest that LMA and SLA can be used to distinguish polluted and clean area efficiently, which is significant for native trees selection in Zhanjiang. As for clean area and polluted area construction, responses of leaf functional traits to different environment are of significance in promotion and application of garden cultural construction.

\section{Acknowledgements}

This research is supported by National Spark Program of China (Grants: 2013GA780075) and Zhanjiang key laboratory project of tropical plant resources and development (No. 2014A06008).

\section{References}

[1] Reich PB, Wright IJ, Cavender-Bares J, et al. The evolution of plant functional variation: Traits, spectra, and strategies. International Journal of Plant Sciences, 143-164.(2003)

[2] Violle C, Navas ML, Vile D, et al. Let the concept of trait be functional! Oikos, 882-892.(2007)

[3] Reich P B, Oleksyn J. Global patterns of plant leaf N and P in relation to temperature and latitude. Proceedings of the National Academy of Sciences of the United States of America. 11001-11006. 2004

[4] Meng T T, Ni J, Wang G H. Plant functional traits, environments and ecosystem functioning. Journal of Plant Ecology. 150-165(2007)

[5] Westoby M., Wright, I.J. Land-plant ecology on the basis of functional traits. Trends Ecology and Evolution.261-268(2006)

[6] DIAZ S,CABIDO M,CASANOVES F. Plant functional traits and environmental filters at a regional scale. Journal of Vegetation Science.113-122(1998)

[7] Atkin, O. K, K. J. Bloomfield, et al. "Global variability in leaf respiration in relation to climate, plant functional types and leaf traits." New Phytologist.614-636 (2015) 
[8] Zhang P P, Li Y Y, Shao M A. Effects of sandy land water habitat and years after rejuvenation pruning on leaf functional traits of Salix psammophila. Chin J Appl Ecol.2240-2246(2011)[in Chinese]

[9] Ishihara M I, Hiura T. Modeling leaf area index from litter collection and tree data in a deciduous broad-leaved forest. Agri For Meteor.1016-1022(2011)

[10] Huang W J, Li Z J, Yang Z P, et al. The structural traits of Populus euphratica heteromorphic leaves and their correlations. Acta Ecol Sin. 4636-4642(2010) [in Chinese]

[11] Ogaya R, Peñuelas J. Leaf mass per area ratio in Quercus ilex leaves under a wide range of climatic conditions: The importance of low temperatures. Acta Oecol, , 168-173(2007)

[12] Ivanova L A. Adaptive features of leaf structure in plants of different ecological groups. Russian Journal of Ecology.107-115(2014)

[13] Swenson N G, Enquist B J. Ecological and evolutionary determinants of a key plant functional trait: wood density and its community-wide variation across latitude and elevation. Durham University. 701-709(2013)

[14] Fu P L, Jiang Y J, Wang A Y, et al. Stem hydraulic traits and leaf water-stress tolerance are co-ordinated with the leaf phenology of angiosperm trees in an Asian tropical dry karst forest. Annals of Botany.189-199(2012)

[15] David H, Barbaroux C, Dufrêne E, et al. Modelling leaf mass per area in forest canopy as affected by prevailing radiation conditions. Ecological Modellin.339-349(2007)

[16] Ogaya R, Peñuelas J. Leaf mass per area ratio in Quercus ilex leaves under a wide range of climatic conditions. The importance of low temperatures.Acta Oecologica.168-173(2007)

[17] Wright I J, Westoby M, Reich P B. Convergence towards higher leaf mass per area in dry and nutrient-poor habitats has different consequences for leaf life span. Journal of Ecology.534-543(2002) 